\title{
Anti-Tumor and Anti-Ovarian Cancer Screening of Compound from the Leaf Methanol Extract of Annona Muricata Linn (Annonaceae)
}

\author{
Cletus .A. Ukwubile*1 ${ }^{2}$ Ikpefan .E. Oise, ${ }^{3}$ Aguh .I. Bruno, ${ }^{1}$ Agu Matthew O, \\ ${ }^{4}$ Cynthia T. Samagoro \\ ${ }^{1}$ Department of Science Laboratory Technology, Federal Polytechnic Bali, Nigeria, \\ ${ }^{2}$ Department of Pharmacognosy and Traditional Medicine, Faculty of Pharmacy, Delta State, \\ University, Abraka, Nigeria. \\ ${ }^{3}$ Department of Biological Sciences, Federal University, Gusau, Nigeria. \\ ${ }^{4}$ Department of Pharmacognosy, Gombe State University, Gombe, Nigeria
}

\begin{abstract}
Ovarian cancer is one of the cause of death from gynaecological complications. Many female patients are often diagnosed with various stages of the disease. Treatment has proven very difficult due to metastasis resulting in multiple infections. The leaves of Annona muricata were extracted and then fractionated by column chromatography. In vitro cytotoxicity tests were performed with fractions and with an isolated compound on ovarian cancer cell line, at concentrations of 6.25-200 $\mu \mathrm{g} / \mathrm{mL}$ for crude extract and pure compound. Cytotoxicity was measured after 24, 48 and 72 hours using MTT assay. In vivo cytotoxicity was tested on ascites, developed in the abdomen of albino mice after inoculation with human epithelia OV7-CDNA$20 \mu \mathrm{L}$ cells intraperitoneally. Cytotoxicity of the crude extract and pure compound for the cell line at all concentrations was greater than $10 \mu \mathrm{g} / \mathrm{mL}$, at 48 hours $(p \leq 0.05$; ANOVA). Both the crude plant extract as well as the pure compound of A. muricata leaf killed the cancer cell at a final concentration of $200 \mu \mathrm{g} / \mathrm{mL}$ and $100 \mu \mathrm{g} / \mathrm{mL}$ respectively at all concentrations. Mean survival time (MST) and percentage increase in life span were highest in group IV with values $3.0 \pm 0.03$ and $5 \pm 0.05$ respectively at $1000 \mathrm{mg} / \mathrm{kg}$ body weight (b.w).Packed cell volume (PCV) and Non-viable tumors cell counts $(N V C)$ showed progressive increase as the dosage increased from $10-1000 \mathrm{mg} / \mathrm{kg}$ in all the groups while viable tumor cell counts decreased in all the groups as compared to doxorubicin. The study showed that A. muricata leaf has potent anti-ovarian cancer effects against ovarian cancer cell line, and represents a source for ovarian cancer therapy.
\end{abstract}

Keywords: Ovarian cancer, Annona muricata, MTT assay, Cytotoxicity, tumor cell.

\section{INTRODUCTION}

Cancer is known medically as a malignant neoplasm, is a broad group of diseases involving unregulated cell growth. In cancer, cells divide and grow uncontrollably, forming malignant tumors, and invading nearby parts of the body. Breast and Ovarian cancers are the commonest of all cancer types; with the ovarian cancer (OVC) a major gynecological problem in developing countries [1]. There are over 100 different types of cancer, and each is classified by the type of cell that is initially affected [2].

Mutation in FOXL2 is the major cause of ovarian cancer. FOXL2 is Forkhead transcription factor which is responsible for normal development of eyelids in newborns, it is also needed to form a full complement of eggs in ovaries before birth is the primary cancer of ovarian cancer. Mutation of FOXL2 can be caused by radiation, chemotherapy and autoimmune disorder. FOXL2 is a transcription factor; meaning it stimulates other genes to turn on or off in the eyelids andthe ovaries [3]. FOXL2 gene is located from base pair 138,944,223 to base pair 138,947,139 on chromosome 3 . Blepharophimosis-ptosis-epicanthus inversus syndrome (BPES) is a genetic disorder characterized by eyelid malformation and ovarian dysfunction [4].

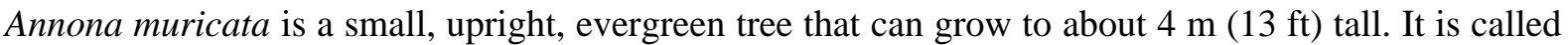
soursop (Graviola) in English due to the sweet and sour flavor of the large fruit, 'Gwanda Masar' in Hausa , and a lowland tropical fruit-bearing tree in the Annonaceae family mainly found in SouthEast Nigerian States of Anambra, Imo, Abia and Enugu. The plant has many uses in traditional medicine. It protects the immune system and avoid deadly infections. Effectively target and kill 
malignant cells in 12 types of cancer, including colon, breast, prostate, lung and pancreatic cancer. The tree compounds (annonacin, annonins, bullatacin, etc) proved to be up to 10,000 times stronger in slowing the growth of cancer cells than Adriamycin (Doxorubicin), a commonly used drug [5].

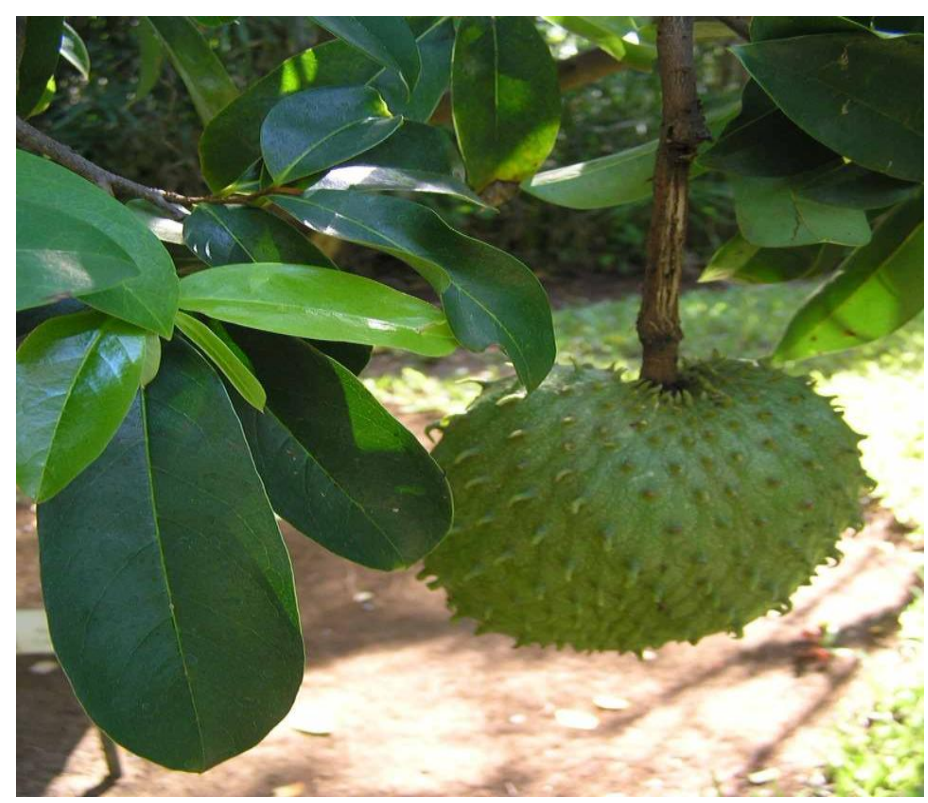

Figure1. Pictorial view of Annona muricata in its natural habitat. Source: Takum Forest Taraba State, Nigeria (June, 2014)

This study was carried out in order to determine the anti-ovarian cancer activities of Annona muricata isolated compound and to study the cytotoxicity of crude extract of leaf and pure compound on ovarian cancer cell line by in vitro and in vivo methods.

\section{Materials ANd Methods}

\subsection{Collection and Identification of Plant}

Leaves of Annona muricata were collected from forests in Takum and Bali L.G.A Taraba State and identified at the herbarium unit of Biology, Federal Polytechnic Bali, Nigeria where voucher number was deposited for the plant.

\subsection{Extraction and Isolation of Annona Muricata Leaf Powder}

Dried ground leaves of Annona muricata weighing 5000g (5kg) were macerated with methanol at room temperature. After 24 hours a crude extract of the leaves was removed and evaporated using rotary evaporator under reduced pressure to yield a dark green extract (500 g, $10 \%$ yield). $3 \mathrm{~g}$ portion of the extracts were fractionated using column chromatography (CC) with $4 \mathrm{~mm}$ thickness silica gel (60-120 Merck, Germany) on a round glass plate eluted with increasing polarity. Elution was carried out with a stepwise gradient consisting of hexane:dioxane, $98: 2(\mathrm{v} / \mathrm{v} 400 \mathrm{~mL})$; hexane: chloroform: dioxane, 88:10:2 (v/v $600 \mathrm{~mL}$ ); hexane:chloroform:dioxane: ethyl- acetate:2-propanol, 80:10:2:6:1, (v/v $600 \mathrm{~mL})$ and hexane: chloroform: acetone: methanol, 56:20:16:8, (v/v $400 \mathrm{~mL})$. A total of 125 fractions $(10 \mathrm{~mL}$ each) were collected .The eluents that showed the same profile on thin layer chromatography (TLC) chromatogram were combined to give four fractions (I-IV). The isolated compound's purity was demonstrated through the observation of only one spot in TLC plate as well as a single peak on HPLC apparatus [5].

\subsection{HPLC Analysis}

HPLC analysis of methanol extract was carried out with chromatographic system (YL 9100,Korea) consist of autosampler (YL 9150) with $100 \mu \mathrm{L}$ fixed loop and an YL9120 UV-Visible detector. The separation was performed on a SGE Protocol PC18GP120 $(250 \mathrm{~mm} \times 4.6 \mathrm{~mm}, 5 \mu \mathrm{m})$ column at ambient temperature. The mobile phase consists of methanol to ethylacetate $(70: 30 \mathrm{v} / \mathrm{v})$ and the separations were performed by using isocratic mode, elution performed at a flow rate of $1 \mathrm{~mL} / \mathrm{min}$. The samples were run for $15 \mathrm{~min}$. and detection was done at $254 \mathrm{~nm}$ by UV detector. All chromatographic data were recorded and processed using autochro-3000 software [5-8]. 


\subsection{Anti-Tumor Study of Leaf Methanol Extract}

Solution of formaldehyde (10\%) was added to $50 \mathrm{~mL}$ distilled water in drinking bottles. The animals were allowed freely to drink the solution ad libitum for one month (i.e. 4 weeks). Prior to tumor induction, the initial weights of the mice were recorded and animals were divided into five groups of six animals each, and were housed separately in cages. Each day the residual drinking solution was measured so that the consumption of each test solution could be calculated; solution $\mathrm{pH}$ was 6.8 to 7.0 [9]. After tumor development, the animals were administered methanol leaf extracts of the crude and pure compounds intraperitoneally. Group I received $5 \mathrm{~mL} / \mathrm{kg}$ normal saline, group II, III and IV received $10 \mathrm{mg} / \mathrm{kg}, 100 \mathrm{mg} / \mathrm{kg}$ and $1000 \mathrm{mg} / \mathrm{kg}$ of crude and pure compound, while group $\mathrm{V}$ received Doxorubicin (Adriamycin ${ }^{\circledR}$ USP) $10 \mathrm{mg} / \mathrm{kg}$ i.p [10]. The animals were observed for two weeks. Tumor parameters were recorded. Haematological parameters such as PCV, Hb, WBC, MCV, MCHC, and $\mathrm{RBC}$ were also determined. The investigations here were based on pure compound isolated from the leaves of Annona muricata methanol extract. Mean survival time (MST) and increase in life span (\%ILS) were calculated using the formulae below respectively:

$$
\begin{aligned}
& M S T=\text { Day of first death }+ \text { day of last death } / 2 \\
& \% I L S=\text { MST of treated group/MST of control group } x 100
\end{aligned}
$$

\subsection{In-vitro Cytotoxicity Assay}

Cytotoxicity assay was carried out in accordance with previously published protocol by [11]. Ehrlich ascites carcinoma cells (EAC) drawn from the animals $\left(5 \times 10^{3}\right.$ cells/well) were cultured on a flatbottomed 96-well plate. After $48 \mathrm{~h}$ incubation, $20 \mu \mathrm{L}$ of MTT solution $(5 \mathrm{mg} / \mathrm{mL})$ was added to each well of the assay plate, which was then incubated for $4 \mathrm{~h}$ at $37^{\circ} \mathrm{C}$. After incubation, the formazan crystals formed by the reduction of tetrazolium salt by the mitochondria of living cells, were dissolved in DMSO. The plates were read in ELISA plate reader at wavelength of $540 \mathrm{~nm}$.

\subsection{Cell Lines Culture}

Cell line used in the assays was epithelial ovarian cancer OV7-96020764-CDNA-(20uL) obtained on demand.

\subsubsection{In Vitro Cytotoxicity Tests with Different Fractions of Annona Muricata}

In vitro cytotoxicity tests were performed using MTT assay as described by Xu-jie and Chu [11]. Briefly, ovarian cell line $\left(5 \times 10^{4}\right)$ was seeded in 24-wells plates (Costar, USA) and grown in RPMI1640, supplemented with $6 \mathrm{mM}$ L-glutamine, 10\% foetal bovine serum (FBS) (Gibco, Invitrogen, UK) and penicillin (100 units $/ \mathrm{mL})$ and streptomycin $(100 \mu \mathrm{g} / \mathrm{mL})$, while normal fibroblasts were grown in Dulbecco's modified Eagle medium (DMEM), also supplemented with L-glutamine and FBS. Cultures were maintained in a humidified atmosphere of $5 \% \mathrm{CO}_{2}$ at $37{ }^{\circ} \mathrm{C}$. Cell cultures, in triplicates, in exponential growth were treated with the different dried fractions of the plant extract, redissolved in di-methyl sulfoxide (DMSO) and added at final concentrations of 1,10 and $100 \mu \mathrm{g} / \mathrm{mL}$. The control cultures had $0.02 \%(1 \mu \mathrm{g} / \mathrm{mL}) 0.2 \%(10 \mu \mathrm{g} / \mathrm{mL})$ and $2 \%(100 \mu \mathrm{g} / \mathrm{mL})$ DMSO added to the medium. In $2 \mathrm{~mL}$ medium/well $10 \%$ MTT was added and $100 \mu \mathrm{L}$ of the supernatants of the 24well plates after 24, 48 and $72 \mathrm{~h}$ incubations were pipetted into 96-well plates. Cell viability was measured with a 96-well plate reader. In a later stage, after identifying fractions with high cytotoxic effects, the final concentrations of extracts tested ranged from $6.25-200 \mu \mathrm{g} / \mathrm{mL}$, with final concentrations of 0.02 up to $0.2 \%$ DMSO.

\subsubsection{In vivo Pilot Experiment}

An in vivo pilot experiment was performed with thirty Swiss albino mice consisting of all females (average weights $18-25 \mathrm{~g}$ ). In order to mimic advanced ovarian cancer, the mice were injected intraperitoneally (i.p.) with $1 \times 10^{4}$ OV7-96020764-CDNA-(20uL) cell line into the abdominal cavity to form ascites. Five groups of mice were examined: four control mice (no treatment), twelve mice treated with crude and pure compound from A. muricata leaf and four mice treated with doxorubicin $(10 \mathrm{mg})$ after ascites had formed. Cells of ascites of two mice were frozen and stored for future experiments. To study the reduction of swollen abdomen, $5 \mathrm{mg} / \mathrm{kg}$ doxorubicin (Rubex) and the isolated compound at a final concentration of $20 \mathrm{mg} / \mathrm{kg}$ were administered i.p. 
Cletus .A. Ukwubile et al.

\section{Results}

Table1. Effect of A. muricata crude/pure compound on body weight after tumor induction/extract treatment

\begin{tabular}{|l|l|l|l|l|}
\hline Groups & weight before Induction & weight after induction of \\
\cline { 3 - 5 } & (g) & Tumor & Extract & Treatment (g) \\
\hline Group1 & 29.5 & 12.0 & $\mathbf{1 5 . 3}$ & $19.2^{*}$ \\
\hline Group2 & 19.6 & 17.5 & $\mathbf{2 3 . 5}$ & $23.8^{*}$ \\
\hline Group3 & 20.4 & 14.7 & $\mathbf{1 8 . 2}$ & $19.4^{*}$ \\
\hline Group4 & 30.2 & 19.4 & $\mathbf{2 0 . 6}$ & $22.5^{*}$ \\
\hline Group5(Control) & 17.8 & 16.3 & $\mathbf{2 2 . 0}$ & $22.2^{*}$ \\
\hline
\end{tabular}

${ }^{\square}$ Results are means of group, figures in bold represent treatment values for crude extracts,

* Values for treatment from pure compounds.

Table2. Survival and tumor incidence in mice given FDH in drinking water

\begin{tabular}{|c|c|c|c|c|c|c|}
\hline \multirow[t]{2}{*}{ Animals groups } & \multirow{2}{*}{$\begin{array}{l}\text { No of survival at following wk after } \\
\text { initiation of treatment } / \mathrm{wk}\end{array}$} & \multicolumn{5}{|c|}{ No of mice with tumors } \\
\hline & & $\mathrm{NC}$ & $\mathrm{LU}$ & LT & $\mathrm{ST}$ & MK \\
\hline Group1 & $6 / 1$ & 4 & 2 & 2 & 4 & 0 \\
\hline Group2 & $6 / 1$ & 4 & 3 & 4 & 3 & 2 \\
\hline Group3 & $4 / 2$ & 4 & 2 & 3 & 4 & 0 \\
\hline Group4 & $4 / 3$ & 4 & 4 & 2 & 5 & 0 \\
\hline Group5(Control) & $4 / 4$ & 3 & 0 & 0 & 1 & 0 \\
\hline
\end{tabular}

${ }^{\square}$ N(nasal cavity), LU(lung), LT(larynx and trachea), ST(stomach), MK(metastasis to kidney)

Table3. Mean survival time and percentage increase in life span after tumor treatment with A. muricata leaf methanol extract

\begin{tabular}{|l|l|l|}
\hline Experimental Group & MST & \% ILS \\
\hline Normal control group1 & - & - \\
\hline $10 \mathrm{mg} / \mathrm{kg}$ group 2 & 2.2 & 35.10 \\
\hline $100 \mathrm{mg} / \mathrm{kg}$ group3 & 2.5 & 37.50 \\
\hline $1000 \mathrm{mg} / \mathrm{kg}$ group4 & 3.0 & 50.50 \\
\hline Grp5doxo.10mg/kg & 3.2 & 53.62 \\
\hline
\end{tabular}

*Mean survival time (MST), Increase in life span(\%ILS), doxo (doxorubicin control drug)

Table4. Effects of methanol extract of Annona muricata leaf extracts on tumor cell volume (TCV), packed cell volume $(P C V)$, viable and non viable cell count on MEAM pure extract tumor-bearing mice

\begin{tabular}{|c|c|c|c|c|c|}
\hline \multicolumn{6}{|c|}{ Tumor Parameters (\%) } \\
\hline Group & Body wt (g) & TCV & PCV & $\mathrm{VCC}$ & NVCC \\
\hline Group1(normal) & 29.50 & 0 & 0 & 0 & 0 \\
\hline Group2(10mg/kg) & 19.60 & 36.50 & 32.00 & 28.20 & 5.00 \\
\hline Group3(100mg/kg) & 20.40 & 35.40 & 33.10 & 22.20 & 5.10 \\
\hline Group4(1000mg/kg) & 30.20 & 33.50 & 34.50 & 20.10 & 6.50 \\
\hline Group5(10mg DRN) & 17.80 & 32.13 & 31.00 & 6.47 & 7.24 \\
\hline
\end{tabular}

Weight of mice tend not to be stable at the doses administered whereas tumor cell volume (TCV) packed cell volume, viable tumor count values increased as the dosage increased in the groups. However, non viable tumor cell count was on the decrease and significantly different from the normal control group at $p \leq 0.05$ (one-way ANOVA).

Table5. Effect pure methanol extract of Annona muricata (MEAM) leaves on haematological parameters in albino mice

\begin{tabular}{|l|l|l|l|}
\hline \multicolumn{3}{|c|}{ Haematological parameters } \\
\hline Animal group & Hb(g) & RBC $(\%)$ & WBC(\%) \\
\hline Group1(normal) & 14.88 & 8.62 & 7.82 \\
\hline Group2 $(10 \mathrm{mg} / \mathrm{kg})$ & 9.82 & 3.81 & 20.07 \\
\hline Group3 $(100 \mathrm{mg} / \mathrm{kg})$ & 10.60 & 4.75 & 32.92 \\
\hline Group4(1000mg/kg) & 11.45 & 5.42 & 49.85 \\
\hline Group5(10mgDRN) & 11.70 & 5.81 & 16.12 \\
\hline
\end{tabular}

* Control (doxorubicin, Rubex) 
Anti-Tumor and Anti-Ovarian Cancer Screening of Compound from the Leaf Methanol Extract of Annona Muricata Linn. (Annonaceae)

Table6. Growth inhibition assay(using human epithelial ovarian cancer cell line OV7-96020764-CDNA-(20uL) from crude plant extracts

\begin{tabular}{|l|l|l|l|l|l|l|l|}
\hline Extract & \multicolumn{6}{l|}{ Concentration $(\boldsymbol{\mu g} / \mathbf{m L})$} \\
\hline & $\mathbf{6 . 2 5}$ & $\mathbf{1 2 . 5}$ & $\mathbf{2 5}$ & $\mathbf{5 0}$ & $\mathbf{1 0 0}$ & $\mathbf{2 0 0}$ & IC50 $(\boldsymbol{\mu g} / \mathbf{m L})$ \\
\hline AML & 38.49 & 58.33 & 56.72 & 89.88 & 92.75 & 91.60 & 10.60 \\
\hline AMSt & 12.93 & 26.46 & 34.07 & 35.93 & 47.14 & 59.63 & 108.35 \\
\hline Control & 19.41 & 52.32 & 77.17 & 78.55 & 68.10 & 66.20 & 120.15 \\
\hline
\end{tabular}

${ }^{\Delta} A M L=A$. muricata leaf extract, $A M S t=A$. muricata stembark, $I C_{50}=$ concentration of tested sample to inhibit $50 \%$ growth of cell line

Table7. Growth inhibition assay (using human epithelial ovarian cancer cell line OV7-96020764-CDNA-(20uL) from pure compound

\begin{tabular}{|l|l|l|l|l|l|l|l|}
\hline Extract & \multicolumn{6}{l|}{ Concentration $(\boldsymbol{\mu g} / \mathbf{m L})$} \\
\hline & $\mathbf{6 . 2 5}$ & $\mathbf{1 2 . 5}$ & $\mathbf{2 5}$ & $\mathbf{5 0}$ & $\mathbf{1 0 0}$ & $\mathbf{2 0 0}$ & IC50( $\boldsymbol{\mu g} / \mathbf{m L})$ \\
\hline AML & 21.88 & 60.52 & 93.85 & 93.34 & 92.75 & 90.37 & 11.29 \\
\hline AMSt & 0.43 & 1.73 & 4.60 & 15.00 & 20.45 & 60.89 & 171.89 \\
\hline
\end{tabular}

${ }^{\Delta} A M L=A$. muricata leaf extract, $A M S t=A$. muricata stembark, $I C_{50}=$ concentration tested sample to inhibit $50 \%$ growth of cell line

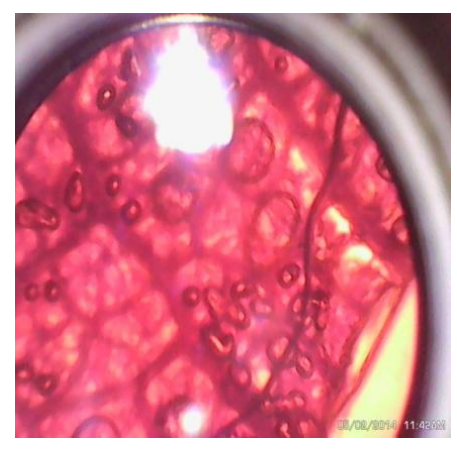

a.

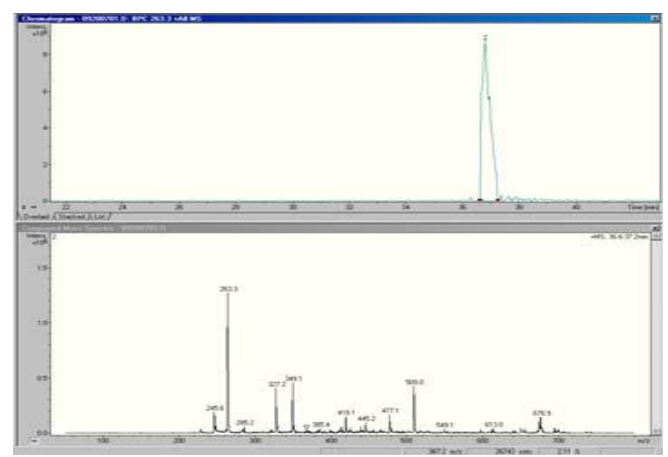

b.

Figure1. Tumor cell as viewed from the microscope (a), and HPLC Standard curve for A. muricata $(b)$
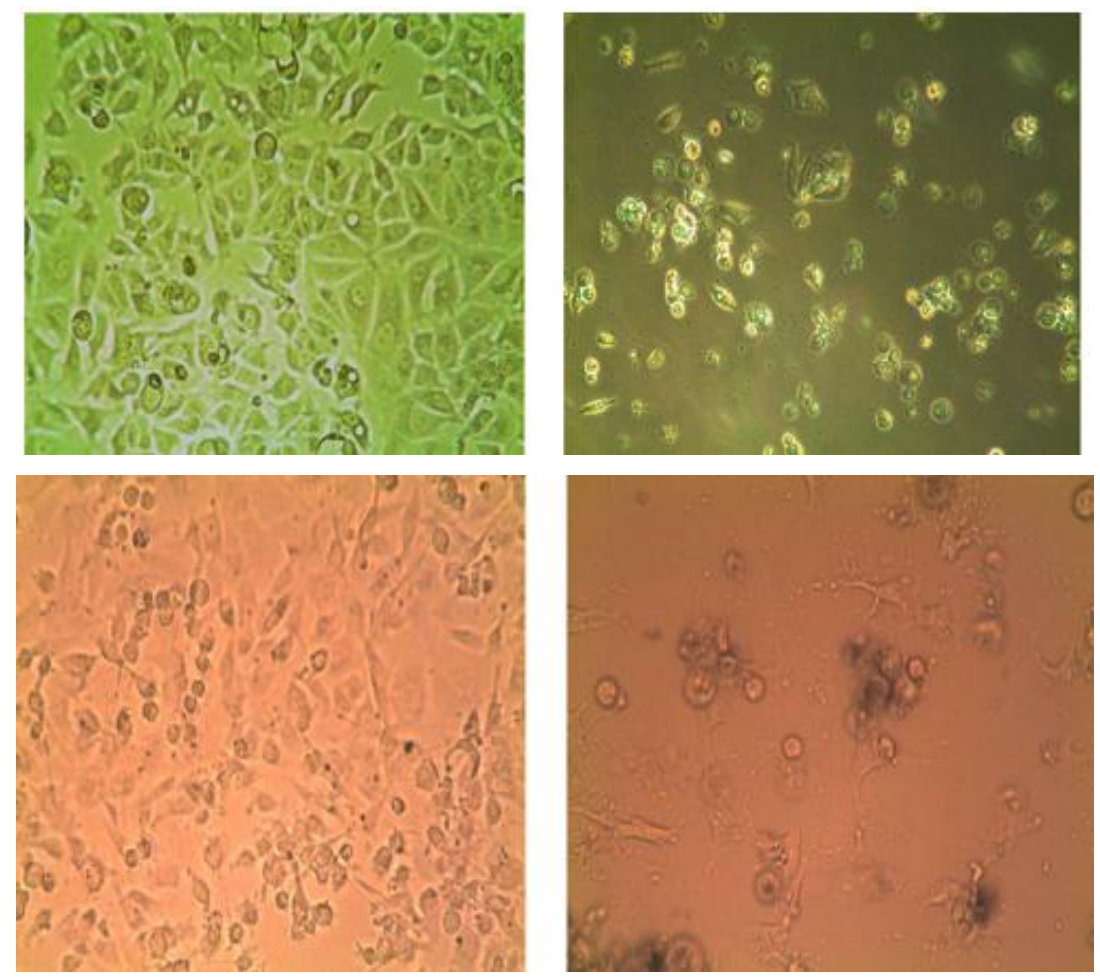

Figure2. Cancer cell healing after treatment with plant extracts, AML(A. muricata leaf), ASL and AMS(A. muricata stembark) $1000 x$ 


\section{DISCUSSION}

Acquired resistance has been a serious problem in cancer therapy. Nanoparticle-based chemotherapy with other anticancer drugs has been an effective way to improve therapeutic outcome .Annona muricata has been a folk medicine for centuries, and its extract has been shown to have cytotoxic and antiproliferative effects in different systems based on its inhibition of diverse cellular events associated with tumor pathogenesis. Ovarian cancer disease is a major problem which still remain unaddressed. Studies on the anti-cancer activities began after the first cytotoxic acetogenin, uvaricin, which was isolated in 1982 [12]. Since then, exponential zeal has been attached to the acetogenins that showed potential to inhibit tumor cells that are resisted by many anti-cancer drugs.

Importantly, Annona muricata inhibit tumor growth in a mouse model with intraperitoneal metastasis ascites formation. With Annona muricata treatment, a remarkable tumor inhibition of > $90 \%$ was achieved. Bioactive compounds are often found in medicinal plant and herbal mixtures, making them a superb source for the discovery of novel drug leads.

A. muricata have the ability to treat wide-ranges of human diseases including twelve types of cancer [13]. There are many studies with evidences to support this claim. Extracts from various parts of $A$. muricata have been reported to show selective cytotoxic effects against various cancer cell lines such as pancreatic cancer, cervical cancer, lung cancer, and breast cancer [14-16].

Following the vast number of $A$. muricata preliminary anti-cancer studies, it was discovered that the major bioactive components known as Annonaceous acetogenins were the major contributor to anticancer activity. Acetogenins are derivatives of long chain $\left(\mathrm{C}_{35}\right.$ to $\left.\mathrm{C}_{37}\right)$ fatty acids derived from the polypeptide pathway. These fatty acids are found connected to a variable number of tetra-hydrofuran or tetra-hydropyran rings and a terminal lactone moiety [17]. The compound isolated from the leaf of A. muricata is not different structurally from other acetogenins in terms of number of carbons. The pure compound isolated Murisolin A had shown very potent cytotoxicity against ovarian cancer cell line in vitro and in vivo than the crude extract and the first line anti-cancer drug adriamycin. The compound isolated from the leaf exhibited anti-ovarian cancer activity with $\mathrm{IC}_{50}$ value of $11.29 \mu \mathrm{g} / \mathrm{mL}$ after $24 \mathrm{~h}$ (Table 7), and this value was significantly different from that obtained from the control group and the crude extract at $\mathrm{p} \leq 0.05$. In table 8 , fraction 2 with ethyl acetate showed most cytotoxicity on the cell line with $100 \%$ inhibition. Some studies have shown the anti-tumor and anticancer property of other Annona species.

Ukwubile and Bibinu 2015[18] carried out a work on the anti-cancer/anti-tumor activity of Annona senegalensis, a plant used in folklore medicine for the treatment of several diseases, and showed that the plant also possess anti-tumor property in mice. A good anti-tumor agent is also a good anti-cancer agent. This is because tumor especially malignant type most often give rise to cancers [19]. GC-MS analysis identified other compounds in the leaf of A. muricata, but of these Murisolin A from NMR elucidation was shown to be responsible for the property investigated in vitro by MTT assay and in vivo mice models. From the results in tables 1-7, tumor parameters and haematological indices such as $\mathrm{Hb}, \mathrm{RBC}, \mathrm{WBC}, \mathrm{PCV}, \mathrm{NVCC}$, etc, showed dose dependent activity in the animal groups, and this suggested very strongly that $A$. muricata possessed anti-ovarian cancer property.

Our study therefore showed that Annona muricata isolated compound possess anti-tumor and antiovarian cancer cell activities in mice.

\section{CONCLUSION}

Annona muricata leaf offers significantly greater medicinal value but the fruits were reported to have more anti-cancer property [20]. Apart from its various medicinal properties, acetogenins in Annona muricata showed potent anti-ovarian cancer activity which selectively attack cancerous cells without harming healthy cells and preventing metastasis. Apoptosis of granulosa cells of the ovary has been initiated by this acetogenin in many organs of cancerous cells of humans. The plant had proved to be an effective anti-tumor and anti-cancer medicinal plant, and thus represents a source for new antiovarian cancer drug discovery.

\section{ACKNOWLEDGEMENT}

The authors sincerely thank Mr. Bulus Auta of the Pharmacology Department, Faculty of Pharmaceutical Science University of Jos, Nigeria for helping us get the mice used in this research, and Mr. Henry Nettey of Department of Pharmaceutics and Microbiology, University of Ghana, Accra. 


\section{REFERENCES}

[1] Madeiros, R., Otuki, M.F., Avellar, M.C., \& Calixto, J.B. Mechanisms underlying the inhibitory actions of the pentacyclic triterpene $\alpha$-amyrin in the mouse skin inflammation induced by phorbol ester 12-O-tetradecanoylphorbol-13-acetate.European Journal of Pharmacology,2007; $55,227-235$.

[2] Gajalakshmi S, Vijayalakshmi S, Rajeshwari Devi V. Phytochemical and Pharmacological Properties of Annona Muricata: A Review.Int J. Pharm. Sci,2012, Vol 4, Issue 2: 3-6.

[3] Mbagwu FN. The allelopathic effects of crude water extracts of Annona muricata on common weeds. International Journal of Natural and Applied Sciences, 2006, Vol 2, No 4 :341-344.

[4] Ottolenghi C, Pelosi E, Tran J, Colombino M, Douglass E, Nedorezov T, Cao A, Forabosco A, Schlessinger D: Loss of Wnt4 and Foxl2 leads to female-to-male sex reversal extending to germ cells. Hum Mol Genet 2007, 16:2795-2804.

[5] Li W, Lu Y, Zheng Q-T, Tan N-H, Li C-M, Zhao J. Study on the spatial structure of annomuricatin A, a cyclohexapeptide from the seeds of Annona muricata. Journal of Molecular Structure. 2007; 827: 145-8.

[6] Vieira GHF, Mourao JA, Angelo AM, Costa R, Vieira R. Antibacterial effect (in vitro) of Moringa oleifera and Annona muricata against gram positive and gram negative bacteria. Rev Inst Med Trop Sao Paolo. 2010; 52: 129-32.

[7] Eparvier V, Nguyen VH, Thoison O, Martin MT, Sevenet T, Gueritte F. Cytotoxic monotetrahydrofuran acetogenins from Disepalum plagioneurum. J Nat Prod. 2006; 69: 128994.

[8] Lee YK, Lee WS, Hwang JT, et al., Curcumin exerts anti-differentiation effect through AMPK $\alpha$ PPAR- $\gamma$ in 3T3-L1 adipocytes and antiproliferatory effect through AMPK $\alpha-C O X-2$ in cancer cells. J Agric Food Chem., 2009; 57:305-310.

[9] Hsu Y, Weng H, Lin S, et al., Curcuminoids-Cellular uptake by human primary colon cancer cells as quantitated by a sensitive HPLC assay and its relation with the inhibition of proliferation and apoptosis. J Agric Food Chem 2007; 55: 8213-8222.

[10] Cao S, Norris A, Wisse JH, et al., Ipomoeassin F, a new cytotoxic macrocyclic glycoresin from the leaves of Ipomoea squamosa from the Suriname rainforest. Nat Prod Res 2007; 21: 872-876.

[11] Wu SB, Ji YP, Zhu JJ, et al., Steroids from the leaves of Chinese Melia azedarach and their cytotoxic effects on human cancer cell lines. Steroids 2009; 74: 761-765.

[12] Anekpankul T, Goto M, Sasaki M, et al., Extraction of anticancer damnacanthal from roots of Morinda citrifolia by subcritical water. Sep Purif Technol 2007; 55: 343-349.

[13] Verma M, Singh SK, Bhushan S, et al., . In vitro cytotoxic potential of Polyalthia longifolia on human cancer cell lines and induction of apoptosis through mitochondrial dependent pathway in HL-60 cells. Chemico-Biol Interact 2008; 171: 45-56.

[14] Sundararajan P, Dey A, Smith A, et al., Studies of anticancer and antipyretic activity of Bidens pilosa whole plant. Afr Health Sci 2006; 6: 27-30.

[15] Cebovic T, Spasic S, Popovic M. Cytotoxic effects of the Viscum album L. extract on Ehrlich tumour cells in vivo. Phytother Res 2008; 22:1097-1103.

[16] Patra JK, Thatoi H, Anticancer activity and chromatography characterization of methanol extract of Heritiera fomes Buch. Ham., a mangrove plant from Bhitarkanika, India. Oriental Pharmacy and Experimental Medicine 2013; 13: 133-142.

[17] Batsa MA, Periyasamy K, Anticancer activity of Excoecaria agallocha leaf extract in cell line model. International Journal of Pharmacy and Biological Sciences 2013; 3:392-398.

[18] Ukwubile CA, Ibrahim BH. Anti-tumor/anti-cancer activities and toxicity assessment of leaf methanol extract of Annona senegalensis Pers. (Annonaceae). Elixir Biosciences 2015; 79 :30315-30318.

[19] McLaughlin JL. Paw paw and cancer: Annonaceous acetogenins from discovery to commercial products. J Nat Prod. 2008; 71:1311-1321. [PubMed: 18598079]

[20] Siegel R, Naishadham D, Jemal A. Cancer statistics. CA Cancer J Clin. 2012; 62:1029.[PubMed: 22237781] 